\title{
DRAMATIC TREATMENTS OF THE CONDE ALARCOS THEME THROUGH JACINTO GRAU
}

\author{
Vernon A. Chamberlin \\ Oklahoma State University
}

The Spanish ballad, Romance del Conde Alarcos y de la Infanta Solisa, has been a source of dramatic material from the Siglo de Oro comedia ${ }^{1}$ down to the contemporary theater. Although the theme is Spanish in origin, its theatrical adaptations have been performed in such diverse places as the court of the Sultan of Constantinople, the stage of Goethe's theater at Weimar, the Astley's Theatre Royal in London, the Tacón Theater in Havana, L'Atelier Theater in Paris, and the Municipal Theater of Prague. ${ }^{2}$ Such well-known men as Lope de Vega, Guillén de Castro, Mira de Amescua, Goethe, Friedrich Schlegel, and Disraeli are all involved in the dramatic history of this theme. For some, its theatrical presentation was an unqualified success; for others, it brought only failure and bitter disappointment. ${ }^{3}$

The most recent interpretation of the ballad is that of Jacinto Grau, written in 1907, and performed in Madrid in 1919, at the Teatro de la Princesa. In the prologue of El Conde Alarcos, Grau mentions his awareness of the previous versions of Lope de Vega, Guillén de Castro, Mira de Amescua, José Jacinto Milanés, and Schlegel. ${ }^{4}$ $\mathrm{He}$ does not state, however, whether his version was influenced by any of these, and the present study attempts to determine to what extent, if any, they served as a source of influence.

The romance itself, which has been called one of the "most beautiful and tender ballads in any language," ${ }^{5}$ recounts how the Conde Alarcos, although now married and the father of children, is forced by the King to murder his wife and fulfill a prior promise of marriage to the Infanta. As Alarcos' wife dies, however, she makes a dire prophecy of divine retribution upon the guilty parties, and within thirty days the King, the Infanta and Alarcos are all dead, having been summoned away for sentencing before God's judgment throne. ${ }^{6}$

There are four Siglo de Oro adaptations, not three as Grau mentions: Lope de Vega's La Fuerza lastimosa, Pérez de Montalbán's El Valór perseguido y traición vengada, Guillén de Castro's El Conde Alarcos, and Mira de Amescua's El Conde Alarcos. That Grau fails to mention the comedia attributed to Lope's biographer, Pérez de Montalbán, may be only a reflection of his judgment about a very inferior reworking of Lope's play. ${ }^{7}$

All four of these dramatists, who were contemporaries, follow the aesthetic tastes of the Siglo de Oro and reflect a common approach to the dramatization of the Alarcos theme. Specifically, they follow Lope's concept of "ponga el caso"s as constituting the sum and substance of Act I. Each playwright devotes the first act to the creation of a fictional background for the wellknown opening lines of the romance:

Retraída está la infanta,--bien así como solía, viviendo muy descontenta-de la vida que tenía. ${ }^{9}$

In the background material supplied in the versions of Lope and Montalbán, the Conde (not called Alarcos in either of these two plays), persuades the Infanta to allow him to enjoy her favors. However, an eavesdropping nobleman succeeds in having the Conde detained that night, and then, embozado, keeps his appointment for him. When the innocent Conde learns of the deception and flees the country, the Infanta is distressed and seeks redress from her father, the King. This brings both 
plays to the opening situation of the original romance.

Guillén de Castro and Mira de Amescua, the latter widely assumed to have plagiarized Castro's comedia, ${ }^{10}$ both create a first act that is entirely different from that of the other two playwrights. They depict Alarcos as the father of a child by his future Condesa. The Infanta succeeds in getting possession of this child and threatens to kill it if its mother does not renounce her plans to marry Alarcos. When the Condesa refuses, the Infanta orders a servant to kill the child and serve its heart on a plate and its blood as aguamanos at the wedding banquet of Alarcos and the Condesa. The resultant uproar and arrests end Act I and prepare for a consideration of the romance itself.

\section{All four comedias now follow Lope's} formula:

en el segundo acto enlace los sucesos, de suerte que hasta medio del tercero apenas juzgue nadie en lo que para. ${ }^{11}$

They then turn to the events of the romance. The Infanta bares her complaint to the King, who commands Alarcos to kill his wife and marry the Infanta. However, in complete disagreement with the romance, the Condesa is never actually killed, but in each play she is granted asylum by a friend. This changes the denoument and eliminates the theme of divine retribution upon the guilty parties. The authors must now create a third act completely outside of the ballad story which provides a typical Siglo de Oro desenlace. Mutual recognition, reconciliation and pairing off of the principal characters takes place. Alarcos always manages to remain faithful to his equally faithful Condesa; the Infanta has her honor restored when it has been truly jeopardized or she may be punished if she is culpable. Even Alarcos' children participate in the desenlace and an especially happy ending compensates Alarcos and his Condesa for their years of cruel separation: their children become members of the royal family, either through marriage or the ab- dication of the Infanta.

Like their Siglo de Oro predecessors, the Romantics were also interested in the Alarcos theme. There are two such adaptations, the first being actually a transitional drama showing marked tendencies of both $\mathrm{Neo}$ classicism and Romanticism. ${ }^{12}$ Performed in 1802 at Weimar, and entitled Alarcos: Ein Trauerspiel in Zwei Aufzügen, Friedrich Schlegel's play is the first to follow the original romance story in detail to its tragic conclusion.

Schlegel, of course, takes certain liberties with the ballad material. One of the most notable of these concerns the murder scene where the Condesa does not wait for Alarcos' action, but instead siezes the dagger that had killed her brother, Don García, and stabs herself. As her life is ebbing away, she seems to have a vision of all the guilty parties, including Alarcos, standing before God's judgment throne. Upon hearing such dire prophecies, Alarcos quickly supplies the coup de grâce. However, divine retribution is swift. Word is brought almost immediately that the King and the Infanta are already dead. Alarcos himself then hears a summons from Divine Justice and has a vision of God's dread judgment throne with its banner of death waving and the bleeding corpse of his wife before it. In a romantic deviation from the romance, Alarcos then commits suicide with the murder weapon.

Another innovation of Schlegel's is the creation of a villainous character named Alvaro, who stimulates the Infanta and Alarcos toward ends which are ultimately destructive. Alvaro desires their marriage so that he may become the power behind the throne when they inherit the kingdom. He has no prototype in either the romance or the Siglo de Oro adaptations.

Schlegel, again at variance with the ballad and the Siglo de Oro adaptations, but in keeping with the aesthetics of Romanticism, emphasizes the passionate nature of the Infanta's feelings for Alarcos. Pulsating with sensuousness, she would drink his 
very soul out through his lips. So afire is she that she even begs the moon to send its rays to cool her. ${ }^{13}$

Whereas Schlegel imbues the Infanta with passionate feelings and follows all details of the romance, Milanés, the Cuban author of the other romantic version, $E l$ Conde Alarcos (1838), allows himself much greater liberty in regard to the plot, and gives a sharper focus to the feelings of the Conde and Condesa. The Infanta makes her customary complaint to the King and he decrees that the Condesa must die. However, for the first time in any Alarcos drama, the King dares not order his vassal to murder the Condesa. The romantically enamored and rebellious Alarcos is not the type to carry out such an order. The task must therefore be entrusted to the official state executioner, who follows the Conde to his country villa. There Alarcos makes a series of valiant efforts to prevent the murder of his beloved Condesa. Finally, however, she succumbs at the hands of the embozado executioner and Alarcos collapses as the tragedy ends.

Unlike Schlegel's version, the only previous tragedy of the theme, Milanés' drama does not follow the romance narration on to its conclusion, but, as in the case of the Siglo de Oro adaptations, omits the concluding part telling of the citation before God's judgment throne and the punishment of all those who had a part in the Condesa's murder. The author's technique in this respect is to have the dying Condesa pardon the Infanta, the King, and the executioner. As Alarcos has openly rebelled against the King's command that his wife must die, and has done everything in his power to save her, he has no guilt to expiate before Divine Justice. By thus omitting the denouement portion of the romance, a less general and a more intensely personal tragedy is effected by the author for the ill-starred romantic protagonists, Alarcos and his Condesa.

Interest in the Alarcos theme persisted into the post-romantic period and there is even one Victorian adaptation. Like Friedrich Schlegel, Benjamin Disraeli also chose the ballad as the subject of his only dramatic work. Written in 1839, Count Alarcos was not performed until 1868, when Disraeli became Prime Minister. Disraeli viewed his five act drama as "an attempt to contribute to the revival of English tragedy." ${ }^{14}$ Porterfield says that it is "throughout a Shakespearian play," and that Disraeli's inspirational source was the romance itself, as translated by John Gibson Lockhart in his Ancient Spanish Ballads. ${ }^{15}$ In spite of this source of inspiration, the plot of Disraeli's tragedy shows only very slight resemblance to the story and spirit of the romance. There is a Count Alarcos who, in this case, wants to get rid of his wife in order to marry the Infanta Solisa to further his own political ambitions. The choice is entirely his own, although he is encouraged, in accord with the ballad, by the King and the Infanta. The former even makes it quite clear that he will abdicate and retire to a monastery, thus giving Alarcos control of the kingdom if he marries the Infanta.

Alarcos' wife, whom he married while in exile, is simply an impediment to his high ambitions. He therefore tries to interest her in other men, attempts to have her killed by a Moor, and is finally forced as a last resort to murder her himself. Unlike her prototype in the romance, the Countess is not told why she must die, and she makes no dire prophecy of retribution for the guilty parties. Nevertheless, word is received almost immediately after her death that the Infanta has been killed by lightning, thus tragically frustrating Alarcos' unbridled ambition to be ruler of the realm, and causing him to collapse as the final curtain falls.

It has been suggested that the reason for Disraeli's radical alteration of the ballad story is to be found in an understanding of his own personal egotism and frustrated ambition. Much like the protagonist of his drama, Disraeli may not have been satisfied with being the first peer of the kingdom, 
but may have secretly desired to marry the royal princess and gain control of the throne itself. ${ }^{16}$

Turning now to the plot of Jacinto Grau's twentieth century drama, one notes that it, like Schlegel's, is essentially the narration of the events in the romance itself. The first line spoken in Grau's play is exactly the same as the opening line of the romance, and with comparatively few additions, the drama follows the story of the ballad to its tragic conclusion. Unlike $\mathrm{Mi}$ lanés' tragedy, which omitted the romance events following the murder of the Condesa, and unlike Schlegel's version which crowded them into the final scene of his second and concluding act, Grau creates an entire third act which takes Alarcos back to the King's Castle, where the effect of the dying Condesa's emplazamiento is fully dramatized in relation to each of the principal characters.

These characters now reflect a uniqueness of interpretation and a degree of intensity not found in any of the previous versions. For the first time one sees an Alarcos who is willing to kill his wife in order to share in the sensual pleasures that the Infanta holds in promise for him. When he asks the Infanta to rescind her demand that his wife must die, she needs only to grasp his hands and move her face close to his in order to change him from a loving husband and father into a sensual murderer.

The King, likewise for the first time, is different from any of his predecessors. No longer a resolute monarch concerned with honor, he is goaded into action only by the Infanta's threat of blackmail concerning his murder of her stepmother, and by her calling him a coward and turning her back on him. Under pressure of the events in the drama his personality disintegrates. The last time he is seen alive, he wails: "Yo fui un Rey! ¡Agora sólo soy de un Rey la sombra! . . . Yo fui un Rey. . . un Rey de Castilla, que supo al mundo entero no temer, que supo conquistar reinos, y vencer enemigos fuertes, $\mathrm{y}$ doblegar califas y re- beldes, y no supo romper el terco albedrío de la su hija ... Yo fui un Rey . . . fui un Rey . . . un Rey de Castilla. . . ."17

The Infanta is, without a doubt, Grau's master creation. Although depicted as a very passionate creature in Schlegel's tragedy, she now reaches a new level of intensity. The author first establishes her passionate desire for Alarcos and then increases its intensity until the culmination is reached in the final moments of the drama. In the scene already noted where she infects Alarcos with some of her sensualness and makes him willing to murder his wife, she openly confesses: "Cerca de vos, Conde, siento yo como si el aire fuera lumbre!,"18 and when the King interrupts them, he exclaims " $i E l$ vuestro respirar se oye como aliento de corzo herido!"19

As she awaits the arrival of Alarcos in the last act, her father tells her, " $\mathrm{El}$ rostro, Infanta, se os torna rojo como si en llamas ardiese!" ${ }^{20}$ Later when she bends over Alarcos, her long red hair spreads over his body like tongues of fire, but the culmination is reached in the final scene when the Infanta has no fear of death or hell. To her, fire and love have become synonymous and her great sensuality will extend far beyond this world. ". . . Yo en ti y tú ya en mí eternamente, nos amaremos en siglos de siglos, ardiendo en llamas, aspirando $y \cdot$ muriendo sin morir." 21

Grau adds one especially significant character, the Nodriza, who gives the audience a last minute explanation for the perniciousness of the Infanta's passion for Alarcos. In the final scene the Infanta and the Conde are depicted as being engulfed in sensuality which even news of the King's sudden death fails to penetrate. The Nodriza comes in brandishing a crucifix before the Infanta and Alarcos. She tells the Infanta that they are doomed to eternal punishment in hell: She informs them that she has spent years slyly developing and nourishing the Infanta's all-consuming passion for Alarcos. She boasts that she started when the Infanta was a baby: ". . . logré 
nutrir tu boca de víbora, malas sangres te di, con el zumo de mis pechos envenenado por ansiares de venganza." 22 The Nodriza reveals that she is a Moor and that her motive has been one of revenge for cruelty inflicted upon her family years before by the King and Alarcos. She did not take her revenge when the Infanta was younger, because being a pure child, the Infanta would have gone to heaven. Therefore, she has spent years waiting for this moment which sends the Infanta to eternal damnation.

However, even this terrible revelation does not break the intensity of the Infanta's feelings for Alarcos, and when the Nodriza exits, waving her crucifix and shouting, "¡Al infierno!," the Infanta concludes the drama by replying: " $\mathrm{AAl}$ infierno, si allí se ama!" 23

In addition to his original creativity concerning the Infanta, Alarcos, the King, and the Nodriza, and in accordance with twentieth-century theatrical aesthetics, Grau is the only dramatist of the Alarcos theme to make the stage directions, the lighting, the costumes, and the color symbolism an integral part of his dramatic artistry. A full page of detailed stage directions precedes each act. Red and black are the predominant colors throughout the drama-red for passion and black for tragedy. Thus red is dominant in the following description of the Infanta: "Sale de su cámara la Infanta, apareciendo como envuelta en fuego, ataviada con el rojo brial del primer acto; sueltos y caídos por la espalda, cual penachos de llamás, los ensortijados cabellos bermejencos. El rostro, de un pálido blanco mate, $y$ los oscuros ojos, relumbrantes de fiebre, por negras ojeras agrandados, conviértenla en viva imagen de una vida vaciada en el deseo terco y profundo de esa locura obstinada sólo a la muerta rendible.". ${ }^{24}$

Moreover as the Countess is being murdered, the action is told, not only by dialogue, but also by means of the stage lighting: "Los pábilos, ya mortecinos, de la lámpara, se desmayan y reaniman fugazmente; relumbran luego con viveza un instante, $y$ expirantes se apagan."25 After the murder, Alarcos reappears almost enveloped in a red curtain which he grasps convulsively. The symbolism intended here may well be the guilt of the murder as well as the Conde's all-engulfing sexual passion for the Infanta. Even the title page of the original edition seems to reflect this symbolism as the words El Conde Alarcos are printed in red and the remaining words, tragedia romanesca en tres actos in black.

An examination of the earlier Alarcos plays shows that they could have had little, if any influence at all on the plot of Grau's interpretation. Strikingly absent are the Siglo de Oro tendencies. There is no first act preceding the opening situation of the romance, just as there is no final act created outside of the ballad narrative which alters its tragic conclusion.

If we compare, now, the other dramatists who have dealt with the theme, it is obvious that Disraeli's version must be dismissed as far afield from the story and spirit of the romance. Milanés completely omits the concluding part of the ballad, which tells of a divine retribution upon the guilty parties. Moreover, he shows Alarcos in Romantic rebellion against his monarch, and focuses the tragic conclusion only upon the ill-fated Romantic lovers, Alarcos and his Condesa.

Thus it is readily seen that Schlegel and Grau are the only dramatists who fully follow the romance to its complete tragic conclusion. Schlegel crowds the divine retribution into the last part of his second and concluding act, while one of the most distinguishing features of Grau's play is the extremely rich and original dramatic interpretation he gives to these events in an entire third act. Grau also dramatizes an entirely different concept of the personalities of Alarcos and the King, adds the Nodriza, and develops in the Infanta fiery passion far beyond that of Schlegel's version. Moreover, he makes the costumes, furnishings, lighting effects and color symbolism all an integral part of his artistic creation. 
However, both authors do give prominence to the passionate nature of the Infanta's feelings for Alarcos, and both create a character not found in the romance to develop and stimulate these feelings. This character, called Alvaro, in Schlegel's play desires the marriage of the Infanta Solisa and Alarcos so that he may be the dominating power behind the throne, while Grau's Nodriza desires to obtain revenge by involving the Infanta in mortal sin that will send her to hell. In Grau's drama the Nodriza's influence is much more significant and, contrary to Schlegel's technique, is not revealed until the last scene of the drama.

In response to an invitation to comment upon this problem of minor similarities between the two dramas, Señor Grau replies: "La obra de Schlegel no ahinca en el tema y no he tomado nada de ella, muy ajena a la mía." 26 .

Regarding the previous works on the theme in general, he says: ". . . no he leído ninguna salvo algunos fragmentos de la de Lope de Vega, y de poco valor psicológico y evocativo. La razón es que como ninguno de esos autores han logrado agotar el tema, no he querido recibir influencia que podía desvirtuar mi concepción profundamente trágica de ese romance castellano que reputó Goethe la mayor tragedia doméstica que conocía." 27 Concerning Disraeli's tragedy, he says simply: "La primera noticia de la obra de Disraeli, se la debo a Vd." 28

In addition, Señor Grau has also imparted the following important information concerning his own creative originality:

Como Vd. verá, si conoce el romance del Conde Alarcos, yo lo he referido sin más alteración que la del carácter de la infanta, fuente y motivo principal de mi obra por su arrebato racial en terca voluntad y pasión dionisiaca, poca considerada en el teatro clásico y moderno, a pesar de constituir la entraña de la raza ́́berica de ciertas zonas. Lo que esencialmente me separa de la dramaturgia hispana, es un instintivo propósito de manejar las grandes fuerzas de la naturaleza libres de toda máscara superpuesta por la emoción cristiana. Me han conmovido mucho las grandes creaciones helénicas, antes de la decadencia griega, donde la religión estaba f́ntimamente ligada a la naturaleza. De ahí la gran fuerza de su arte. Nietzsche ha visto esto como nadie. Cuando un creador máximo cual Shakespeare, toma un asunto como El Mercader de Ve. necia o El Othello de los cuentos italianos y agota el tema, realizando obra capital, ningún auténtico artista o poeta, a mi juicio, debe volver a tocar esa obra. Pero cuando no sucede así, como Don Juan - El Conde Alarcos, le está permitido a un autor intentar la obra cumbre. . . . .

Only time will tell if Jacinto Grau has succeeded in his avowed desire to create the final and culminating dramatic version of the Alarcos theme. Suffice it to say for the present that he has created an independent version, in many respects completely different from any previous Alarcos drama, and has thereby greatly added to the rich and varied dramatic interpretations of the intriguing but very challenging theme.

\section{NOTES}

${ }^{1}$ For a discussion of whether or not Torres $\mathrm{Na}$ harro's pre-Golden Age Comedia Serafina (1517?) reflects influence of the Alarcos theme, see Timothy Pickering, "A Note on the "Comedia Serafina' and 'El Conde Alarcos'," MLN, LXx (1956), 109-114.

2 Constantinople: Lope de Vega's version; Weimar: Friedrich Schlegel's; London: Disraeli's; Havana: Milanés'; Paris and Prague: Jacinto Grau's.

3 For the failure of Schlegel and Disraeli's versions, see Carl von Beaulieu-Marconnay, "Goethe's Cour D'Amour," in Goethe-Jahrbuch, vi (1885), 73; and Allen W. Porterfield, "The Alarcos Theme in German and English," GR, vr (1931), 133-134.

"Jacinto Grau, "Prólogo[a] 'El Conde Alarcos'," in Jacinto Grau: Teatro (Buenos Aires, 1954), p. 17.

${ }_{5}$ George Ticknor, History of Spanish Literature, 2nd ed. (New York, 1854), 1, 127, n. 34.

6 The text of the romance with critical notes may be consulted in. S. Griswold Morley, Spanish Ballads (New York, 1911), pp. 64-72. See also Vernon A. Chamberlin "Origin and Significance of the name Alarcos," Symposium, xirI (1959), $117-120$.

7 See Adolph Shaeffer, Geschichte des Spanischen Nationaldramas (Leipzig, 1890), I, 447; and Irving A. 'Leonard, "Montalbán's 'El Valor perseguido' and the Mexican Inquisition, 1682," $H R, x I$ (1943), 53.

8 Lope de Vega, "Arte nuevo de hacer comedias," in Obras escogidas (Madrid, 1946), II, 1446.

9.Morley, Spanish Ballads, p. 64, lines 1-2. 10 See Emilio Cotarelo y Mori, Mira de Amescua $y$ su teatro (Madrid, 1931), p. 68; and Adrian $\mathrm{T}$. Pickering, "Mira de Amescua, 'El Conde Alarcos': A Critical Edition With Introduction and Notes" (unpubl. diss. Ohio State Univ., 1951), p. lxxxii.

${ }_{11}$ Lope de Vega, loc cit. 
12 For a detailed discussion of the romantic aspects of Schlegel's play as compared with that of Milanés, see Vernon A. Chamberlin, "Schlegel y Milanés: dos dramas románticos sobre el tema del Conde Alarcos," Hispanófila, III (1958), 27-38.

${ }_{13}$ Friedrich Schlegel, "Alarcos: Ein Trauerspiel," in Dramen der Frühromantik, ed. Paul Kluckhohn (Leipzig, 1936), p. 297.

${ }^{14}$ Allen W. Porterfield, "The Alarcos Theme in German and English," GR, vi (1931), 133.

15 Porterfield, loc cit.

16 Porterfield, 139.

17 Jacinto Grau, "El Conde Alarcos," in Jacinto Grau: Teatro (Buenos Aires, 1954), pp. 80-81.
18 Grau, "Alarcos," p. 48.

19 Grau, "Alarcos," p. 49.

${ }^{20}$ Grau, "Alarcos," p. 75.

${ }^{21}$ Grau, "Alarcos," p. 83.

22 Grau; "Alarcos," p. 87

${ }^{2.3}$ Grau, "Alarcos," p. 88.

24 Grau, "Alarcos," p. 72.

25 Grau, "Alarcos," p. 65.

${ }^{26}$ Information in a letter to the author from Sr. Jacinto Grau, Buenos Aires, Argentina, July 8, 1953.

${ }_{27} \mathrm{Grau}$, Letter to the author.

28 Grau, Letter.

$29 \mathrm{Grau}$, Letter. 